\title{
Alcohol and Smoking Mediated Modulations in Adaptive Immunity in Pancreatitis
}

\author{
Rakesh Bhatia ${ }^{1}$, Christopher Thompson ${ }^{1}$, Koelina Ganguly ${ }^{1}$, Shailender Singh ${ }^{2}$, \\ Surinder K. Batra $1,3,4, * \mathbb{1}$ and Sushil Kumar $1, *$ \\ 1 Department of Biochemistry and Molecular Biology, University of Nebraska Medical Center, \\ Omaha, NE 68198-5870, USA; rocky.bhatia@unmc.edu (R.B.); c.thompson@unmc.edu (C.T.); \\ koelina.ganguly@unmc.edu (K.G.) \\ 2 Division of Gastroenterology-Hepatology, Department of Internal Medicine, University of Nebraska Medical \\ Center, Omaha, NE 68198-5870, USA; shailender.singh@unmc.edu \\ 3 Fred and Pamela Buffett Cancer Center; University of Nebraska Medical Center, Omaha, NE 68198-5870, USA \\ 4 Eppley Institute for Research in Cancer and Allied Diseases, University of Nebraska Medical Center, \\ Omaha, NE 68198-5870, USA \\ * Correspondence: sbatra@unmc.edu (S.K.B.); skumar@unmc.edu (S.K.)
}

Received: 7 July 2020; Accepted: 6 August 2020; Published: 11 August 2020

check for updates

\begin{abstract}
Pancreatitis is a condition of pancreatic inflammation driven by injury to the pancreatic parenchyma. The extent of acinar insult, intensity, and type of immune response determines the severity of the disease. Smoking, alcohol and autoimmune pancreatitis are some of the predominant risk factors that increase the risk of pancreatitis by differentially influencing the adaptive immune system. The overall decrease in peripheral lymphocyte (T-, B- and (natural killer T-) NKT-cell) count and increased infiltration into the damaged pancreatic tissue highlight the contribution of adaptive immunity in the disease pathology. Smoking and alcohol modulate the responsiveness and apoptosis of T- and B-cells during pancreatic insult. Acute pancreatitis worsens with smoking and alcohol, leading to the development of systemic inflammatory response syndrome and compensatory anti-inflammatory response syndrome, suggesting the critical role of adaptive immunity in fatal outcomes such as multiple organ dysfunction. The presence of $\mathrm{CD} 4^{+}$and $\mathrm{CD} 8^{+} \mathrm{T}$-lymphocytes and perforin-expressing cells in the fibrotic tissue in chronic pancreatitis modulate the severity of the disease. Due to their important role in altering the severity of the disease, attempts to target adaptive immune mediators will be critical for the development of novel therapeutic interventions.
\end{abstract}

Keywords: pancreatitis; adaptive immunity; alcohol; smoking; acute pancreatitis; chronic pancreatitis; lymphocytes; pancreatic stellate cells; collagen

\section{Introduction}

The pancreas is a unique organ due to the presence of its exocrine and endocrine compartments. The pancreatic acini perform an exocrine function by producing proteolytic enzymes as inactive precursors, which are activated in the intestinal lumen. The premature activation of these proteolytic enzymes in the pancreas, predominantly due to dysfunctional calcium homeostasis, leads to pancreatic autodigestion, which elicits an acute local inflammatory response, termed acute pancreatitis (AP). The release of pro-inflammatory cytokines by injured acini leads to leukocyte infiltration, which further releases a gamut of inflammatory mediators that aggravate tissue injury, as well as local and systemic inflammatory responses. The common etiological factors for acute pancreatitis include alcohol, smoking, gallstones, autoimmunity and genetic susceptibility. These etiological factors predispose the pancreas to recurrent AP (RAP), resulting in activation of pancreatic stellate cells (PSC), which leads to 
the displacement of pancreatic parenchyma with extensive fibrosis and extracellular matrix (ECM) proteins, a condition known as chronic pancreatitis $(\mathrm{CP})$.

Sarles et al. first demonstrated the involvement of immune-mediated mechanisms in pancreatitis pathology [1]. An initial event during AP is the recruitment of neutrophils, which are otherwise untraceable in the normal pancreas [2]. Subsequently, there is recruitment of other immune cells from the innate and adaptive arm, such as monocytes, dendritic cells (DCs), T- and B-lymphocytes, as well as platelets. The presence of nicotinamide adenine dinucleotide phosphate (NADPH) oxidase in infiltrating neutrophils ameliorates oxidative stress, contributing to trypsin activation and increased damage to the pancreatic acinar cells [3]. Chemokines, such as CCL2, CCL3 and CCL5, released from the damaged acinar cells, lead to the recruitment of monocytes [2,4], and activated monocytes further amplify the inflammatory response by increasing the production of TNF- $\alpha$, IL-1 and IL-6, promoting disease progression [5]. Macrophages are the major source of IL-6, which is differentially regulated in cerulein-induced murine models of pancreatitis and is associated with acute injury $[6,7]$. Akin monocytes and macrophages, DCs, also serve as a warehouse for various pro-inflammatory mediators of acinar cell damage. However, DCs have been shown to play a dichotomous role in AP due to their ability to promote or suppress the inflammatory response $[8,9]$. Studies have demonstrated the involvement of DCs in restraining the disease, observing that systemic depletion of DCs leads to severe acinar cell damage, increased pancreatic dysfunction and mortality [10]. DCs have also been shown to contribute significantly to the pathology of $\mathrm{CP}$, by modulating the adaptive immune system. Therefore, both innate and adaptive immune arms have a significant role in the initiation of pancreatitis and its severity, as well as in multiple organ failure (MOF). The participation of innate immune mediators such as neutrophils, monocytes and DCs in modulating the severity of AP has been discussed elsewhere [8,11-13]. However, the selective contribution of the adaptive immune arm, i.e., T- and B-lymphocytes, in modulating disease severity during acute and chronic pancreatitis has scarcely been reviewed. Therefore, this review highlights the role of the adaptive immune response and environmental factors like smoking and alcohol in influencing and orchestrating the pathology and severity of acute and chronic pancreatitis.

\section{Role of Adaptive Immune Mediators in Pancreatitis}

The severity of AP depends upon the balance between the pro- and anti-inflammatory responses during disease progression [9]. The contribution of adaptive immune mediators in pancreatitis pathology is demonstrated in athymic or mice deficient in $\mathrm{CD}^{+}$and CD8 ${ }^{+} \mathrm{T}$-cells [14]. That study suggested the role of $\mathrm{CD} 4^{+}$T-cells in tissue injury during AP. Furthermore, an increased lymphocyte flux into the injured pancreas and an overall decrease in peripheral B- and T-cell numbers have been observed in AP. This decrease in lymphocyte count is further aggravated as the severity of disease worsens. Markedly high levels of infiltrating cytolytic lymphocytes, such as CD8 ${ }^{+} \mathrm{T}$-cells, natural killer (NK) cells and NKT-cells have also been observed in pancreatic tissues of $\mathrm{CP}$ patients. $\mathrm{CP}$ patients have higher IL-10-producing Foxp3 ${ }^{+}$regulatory T-cells, which suppresses the proliferation of autologous T-cells in an antigen-specific manner [15]. The overall intrapancreatic increase in regulatory T- and B-cell numbers during AP onset is the predictor of MOF and the severity of AP. Figure 1 shows the crosstalk between immune mediators (adaptive and innate) in aggravating disease severity in AP and $\mathrm{CP}$. 


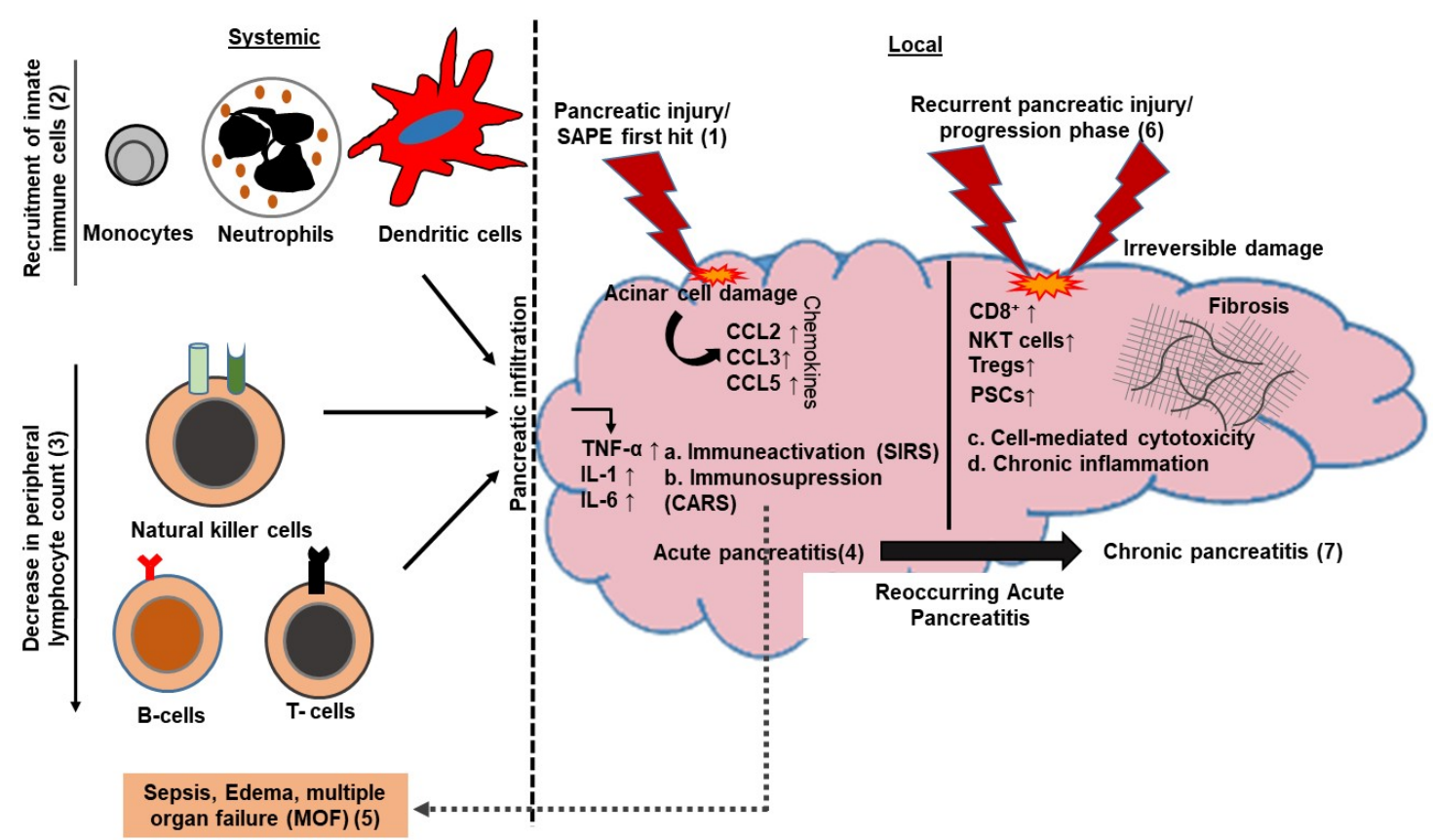

Figure 1. Sequential events involving adaptive immune mediators in clinical progression of the disease. Initial pancreatic acinar cell damage (1) by either trypsin autodigestion or any other insult release various chemokines, resulting in the recruitment of innate immune effectors (2) at the site of injury/damage. This follows the increased lymphocyte infiltration into the pancreas, resulting in a significant reduction of peripheral lymphocyte count (3). Infiltrating immune cells lead to the release of various pro-inflammatory cytokines, resulting in immune hyper-activation (a) due to uncontrolled local inflammatory response. Initial immune-hyper-activation is followed by a phase of immunosuppression (b), leading to a compensatory anti-inflammatory response, resulting in sepsis and edema due to secondary infections and, ultimately, multiple organ failure (MOF) (5). Chronic pancreatitis (CP) (7) is a state of chronic inflammatory response (d) caused by recurrent pancreatic injury (6), leading to irreversible damage, an increased cytotoxic cell (c) infiltration and activation of pancreatic stellate cells, promoting necrosis and fibrosis. Smoking and alcohol are among the major contributing factors for the progression of acute pancreatitis (AP) (4) to CP (7). SAPE; sentinel acute pancreatitis event. CARS; compensatory anti-inflammatory response syndrome.

\subsection{Adaptive Immunity in Acute Pancreatitis}

The infiltrating lymphocytes play an important role in AP. Their genetic ablation in AP mouse models shows reduced disease severity compared to wild-type controls $[14,16,17]$. Initial AP episodes are characterized by immunosuppressive events with overall T- and B-lymphocyte impairment [17-19], followed by a decrease in T- and B-lymphocytes in circulation, associated with the severity of the disease. Among T-lymphocytes, $\mathrm{CD}^{+}$T-cells peripherally deplete to a greater extent than $\mathrm{CD} 8^{+}$ T-cells in both moderate acute pancreatitis (MAP) and severe acute pancreatitis (SAP), due to their increased infiltration from blood vessels to the site of injury bordering acini [14]. The increased T-cell infiltration into the inflamed pancreas is due to the systemic increase in IL-6 and CXCR2-ligands from the acinar cells and increased pro-inflammatory cytokine production from innate immune cells during $\mathrm{AP}[9,20]$. During MAP, as the disease resolves, the $\mathrm{CD} 4^{+} \mathrm{T}$-cell number returns to the normal range; however, the number remains low if the disease progresses to SAP, characterized by necrosis and tissue abscess $[17,21]$. The overall decrease in $T$ helper cell count has been attributed to pancreatic necrosis and the presence of injury-induced endotoxins in circulation from the gastrointestinal tract [18]. However, the $\mathrm{CD}^{+} \mathrm{T}$-cell population remains unaltered. Of note, an increase in AP pathology by infiltrating $\mathrm{CD} 4^{+}$ T-cells is not mediated through their cross-activation by antigen-presenting cells (APCs); however, 
the T-cell mediated cytotoxicity is driven by Fas-Fas ligand activation, as confirmed by increased Fas ligand mRNA expression following cerulein injections, resulting in increased necrosis [14].

Apart from the pancreatic infiltration, the overall reduction in T-lymphocytes in AP is further supported by decreased levels of T-cell survival factor, IL-2, in mononuclear splenic cells in the AP murine model [22]. High expression of CD95/Fas-R/Apo-1 receptor proteins and annexin-V staining also suggests T-cell apoptosis as the major reason for decreased $\mathrm{CD} 4^{+} \mathrm{T}$-lymphocytes during the early course of disease [17]. The onset of AP may lead to systemic immunological response syndrome (SIRS), MOF or mortality, depending upon the disease severity [23]. Activated lymphocytes (T- and B-cells) are central to the onset of the SIRS response. Initially, the progression of AP towards SIRS is due to immune hyper-activation caused by an uncontrolled local inflammatory response, leading towards the excessive systemic activation of peripheral inflammatory cells. As SIRS progresses, increased intracellular activation of caspases leads to the induction of apoptosis of circulating CD4 ${ }^{+}$ T-lymphocytes and increased NK cell activation [24]. However, inflammatory conditions persisting for more than two weeks leads to compensatory anti-inflammatory response syndrome (CARS), creating an immunosuppressive environment, leading to increased susceptibility of necrotic tissue to infections by intestinal flora and secondary MOF [25-27].

According to the revised Atlanta classification, 2012 [28], if the organ failure persists for more than $48 \mathrm{~h}$, it is categorized as persistent organ failure (POF), otherwise known as transient organ failure (TOF). Recent studies demonstrated altered T- and B-lymphocyte levels as a predictor of organ failure in AP $[29,30]$. There is a significant increase in B-cell count in patients with OF, in contrast to the lower $\mathrm{CD} 4^{+} \mathrm{T}$-cell numbers. Importantly, the decrease in $\mathrm{CD} 4^{+} \mathrm{T}$-cell numbers was significant across all etiologies; however, the increase in B-lymphocyte count was only significant in gallstone-mediated $\mathrm{AP}$ [30]. A decrease in $\mathrm{CD} 4^{+} \mathrm{T}$-cell count, resulting in increased immunosuppression, is speculated to be one of the causes of OF [30]. In addition, a study on 39 patients with POF and 30 patients with TOF demonstrated a significant reduction in the total number of peripheral $\mathrm{CD} 4^{+} \mathrm{T}$-cells in the patients with POF, suggesting its utility as a potential indicator for POF during AP [29].

Studies on murine models of experimental pancreatitis also demonstrated that T-lymphocytes influence the innate immune response. $\mathrm{CD}^{+}$T-lymphocytes, after infiltrating into the pancreas, are involved in promoting macrophage activation and Fas-Fas ligand-mediated cytotoxicity during the early onset of AP [21]. A decrease in the number of IL-22 ${ }^{+} \mathrm{CD} 4^{+} \mathrm{T}$-cells during AP leads to increased disease aggressiveness. The IL-22 receptor A1 (IL-22RA1) is expressed on acinar cells responding to IL-22, which protects the acinar cell from apoptosis by activating signal transducers and activators of transcription 3 (STAT3) signaling [31]. Altogether, the early detection of Th1 cytokines in the blood is a predictor of the severity of AP in patients. The course and magnitude of T- and B-cell depletion are similar in MAP; however, a comparatively higher B-lymphocyte reduction is observed in SAP, as shown by a shift in the $\mathrm{CD} 7^{+} / \mathrm{CD} 19^{+}$ratio [17]. A decrease in regulatory B-cells (B-regs) is also associated with increased severity of AP. A study showed a decrease in CD19 ${ }^{+} \mathrm{CD} 24^{\text {hi }} \mathrm{CD} 27^{\text {hi }}$ memory B-cells and IL-10-producing B-cells in patients with SAP. In addition, CD19 ${ }^{+} \mathrm{CD} 24^{\text {hi }} \mathrm{CD} 27^{\text {hi }}$ memory B-cells also suppressed cytokine production from $\mathrm{CD} 4^{+} \mathrm{T}$-cells and $\mathrm{CD} 14^{+}$monocytes in AP. Usually, B-regs release an abundant amount of IL-10 and TGF $\beta$, leading to immunosuppression and induction of T-reg populations. However, in AP, these cells showed abnormal functions and were implicated in the reduction of cytokine production from $\mathrm{CD} 4^{+} \mathrm{T}$-cells, inducing an impaired $\mathrm{CD} 4^{+}$ T-cell response [32]. The precise mechanism by which these B-lymphocytes perform different functions remains unaddressed. Taken together, the apoptotic environment created by infiltrating $\mathrm{T}-$ and B-lymphocytes during the disease onset leads to exposure to pancreas-specific antigens, generating an acute inflammatory response and increased severity in AP.

\subsection{Adaptive Immunity in Chronic Pancreatitis}

Unlike AP histology with prominent necrosis and inflammation of pancreatic acini, CP is a persistent pancreatic inflammatory syndrome encompassing tissue fibrosis, deposition of ECM proteins 
and acinar cell atrophy. Patients with $\mathrm{CP}$ have a higher risk of getting pancreatic cancer, and the risk is even higher in patients with hereditary pancreatitis $[12,33,34]$. Unlike AP, CP leads to irreversible damage to the pancreas, leading to gross pancreatic exocrine and endocrine insufficiencies. Clinically, $4-24 \%$ of patients have been reported to progress from recurrent AP to $\mathrm{CP}$, and the incidence is higher in alcohol and tobacco users. This is further supported by the fact that $78 \%$ of patients progressed to $\mathrm{CP}$ from recurrent $\mathrm{AP}$ who continued to consume alcohol [11]. Compared to the normal pancreas, increased lymphocyte numbers are observed in pancreatic tissue in CP. The CD8 ${ }^{+}$ T-cells are considered to be predominant contributors to disease severity during $\mathrm{CP}$, populating and residing between the pancreatic parenchyma and the fibrotic area. CD8 ${ }^{+} \mathrm{T}$-cells expressing CD103 $(\alpha E$-antigen), analogous to intestinal epithelial lymphocytes, are also present between ductal cells in $\mathrm{CP}$ [35], suggesting the protective role of these cells against the damaging effects of epithelial cells. Cell-mediated cytotoxicity by $\mathrm{CD}^{+}$T-cells or NKT cells is hypothesized to be the major player in CP pathology $[35,36]$. The infiltration of perforin-expressing CD8 ${ }^{+} \mathrm{T}$-cells and, to some extent, CD56 $6^{+}$ NKT cells [36], abundance of $\mathrm{CD} 8^{+}$memory T-cell subsets [15] and the association of CD8 ${ }^{+} \mathrm{T}$-cells with pancreatic acinar cells and fibrotic tissue [37] establishes the involvement of the cytotoxic immune response in $\mathrm{CP}$. Increased $\mathrm{CD} 8^{+} \mathrm{T}$-cell infiltration and presence is observed in interlobular connective tissue and parenchyma in the $\mathrm{CP}$ model of male Wistar rats with increasing disease severity. The CD8 ${ }^{+}$ T-cells come in close association with acinar cells, leading to their apoptosis and replacement by fibrotic compartments [37]. Treatment of mice with T-cell suppressant Tacrolimus rescued acinar cell apoptosis, suggesting an association between T-cells and acinar cells during the development of CP. CP involves a cascade of inflammatory and suppressive events, as demonstrated by the increased number of IL- $10^{+} \mathrm{IFN} \gamma^{-} \mathrm{FoxP}^{+}$T-regs against pancreatitis-associated antigens, counteracting the damage caused by cytotoxic cells in CP [15]. In addition, the restoration of the immunosuppressive environment with increased T-reg cells and the elimination of chronic inflammatory focus upon pancreatic head resection in $\mathrm{CP}$ patients have established the role of infiltrating $\mathrm{CD}^{+} \mathrm{T}$-cells in $\mathrm{CP}$ pathology [38].

There is an increase in intracellular reactive oxygen species (ROS) associated with CP progression and fibrogenesis. In the L-arginine based CP model, Chen et al. tested the therapeutic potential of hydrogen treatment as a potent scavenger of hydroxyl radicals. There was an overall improvement in CP pathology upon hydrogen treatment, as L-arginine-induced pancreatitis leads to ROS-mediated T-lymphocyte apoptosis, especially T-regs, and restoration of depleted T-regs by hydrogen treatment decreased disease severity and promoted their survival [39]. Apart from the pancreatitis-associated antigens and IL-10-producing FoxP3 ${ }^{+}$T-regs, $\mathrm{CP}$ patients have an increased number of antigen-specific CCR7 ${ }^{+} \mathrm{CD} 45 \mathrm{RA}^{-}$central memory T-cells as compared to the healthy and CP-resected controls [40]. T-cells derived from CP patients responded towards pancreatitis-associated antigens, increasing IL-10-based responses; however, the T-cells obtained from pancreatic cancer patients responded towards pancreatic cancer-associated antigens, resulting in high IFN- $\gamma$ levels. This shows that $\mathrm{CP}$ patients have more of an immunosuppressive environment, involving higher T-reg activity [11]. Unlike FoxP3 ${ }^{+}$T-reg cells, which are involved in suppressive function, increased memory T-cells are implicated in maintaining the inflammatory environment in $\mathrm{CP}$. The $\mathrm{CP}$ patients have a 16-fold higher chance of progression towards pancreatic carcinoma, and Th2 cells are among the major contributors to this. Th2 cells also contribute to pancreatic inflammation, and the activated DCs are responsible for skewing T-cell differentiation into the Th2 phenotype upon MyD88 inhibition. This activation of DCs by the MyD88 blockade, resulting in the Th2 phenotype, leads to increased inflammation and fibrosis during $\mathrm{CP}$ and promotes ductal transformation [41]. Along with lymphocytes, pancreatic stellate cells (PSCs) promote CP pathology by promoting tissue fibrosis. PSCs are activated during $\mathrm{CP}$ by a number of toxic and immune-modulatory factors, such as ethanol, smoking, cytokines and chemokines, leading to either synthesis or degradation of ECM proteins. These activated stellate cells, together with T- and B-lymphocytes, increase the inflammatory response and ECM deposition in the pancreas as the $\mathrm{CP}$ becomes more severe. 


\section{Smoking and Alcohol-Mediated Modulation of Adaptive Immunity in Pancreatitis}

Smoking and alcohol are among the common epidemiologically established risk factors for pancreatitis. Studies show that smokers and alcoholic patients exhibit a higher risk of recurrent AP, leading to the progression of CP. Smoking synergizes the effect of alcohol toxicity and predisposition towards pancreatic disorders. For instance, more than $80 \%$ of patients with alcohol-induced chronic pancreatitis are smokers or use tobacco [42]. Overall, smoking and alcohol show profound effects on humoral or adaptive immune effector function. Continuous smoking and heavy alcohol consumption act as a metabolic stress factor to the immune system, which in turn leads to an altered immune response, resulting in increased anti-inflammatory cytokine production and fibrosis [43]. The synergism between alcohol and smoking in promoting pancreatitis follows the "multiple hits on multiple targets" model, which involves crosstalk between multiple pathways, leading to exacerbated acinar damage during pancreatitis. At the cellular level, alcohol and smoking together increase ER stress, elevate intracellular calcium levels, promote mitochondrial damage, increase oxidative stress, activate PSCs and increase pancreatic fibrosis. Among these pathways, Lugea et al. showed that smoking and alcohol predominantly induce an unresolved ER stress response and amplify the risk and severity of pancreatitis $[44,45]$. Persistent smoking and incidence of $C P$ follow a dose-response curve [46]. The major complication of prolonged smoking is the calcification of pancreata and exocrine insufficiency [47].

Smoking significantly alters T-(CD4 ${ }^{+}$and $\left.\mathrm{CD}^{+}\right)$and B-lymphocyte function through alpha 4 and alpha 7 nicotine acetylcholine receptors $(\alpha 4 / \alpha 7 n A C h R)[48,49]$. Upon nicotine exposure, these receptors induce Th17 $7^{+}$T-cell-mediated inflammation and auto-reactive B-cells, resulting in asthma or other atopic diseases [50]. Chronic smoke exposure (CSE) alters overall T-cell responsiveness by decreasing cell proliferation, inhibiting antibody forming B-cells and inducing T-cell anergy. This effect is mediated by the depletion of intracellular $\mathrm{Ca}^{2+}$ stores, which accounts for the overall loss of T-cell function and aberrant signaling [51]. CD8 ${ }^{+} \mathrm{T}$-cell knockout mice were unable to respond to CSE as CD8 ${ }^{+}$cells secrete IP-10 upon CSE, which in turn activates macrophage elastase, resulting in elastin fragmentation and injury [52]. $\mathrm{CD}^{+} \mathrm{T}$ cells are the major source of IL-22 in the pancreas [31]. Cigarette smoke contains different AhR (aryl hydrocarbon receptor) ligands, such as dioxin and benzo (a) pyrene (BaP) $[53,54]$. AhR activation by these ligands leads to increased IL-22 production by CD4 ${ }^{+}$T-cells, which in turn promotes tissue fibrosis by PSC activation and ECM deposition [47,55]. Mechanistically, components of cigarette smoke, such as nicotine and NNK, activates AhR signaling and promotes the expression of IL-22 in CD4 ${ }^{+}$T-cells. The IL-22 receptor (IL22RA1) present on the surface of PSCs actively responds to IL-22 secreted from T-lymphocytes, leading to phosphorylation of STAT3, which then translocates into the nucleus, resulting in upregulation of ECM proteins such as collagen 1A1 (COL1A1) and fibronectin 1 (FN1). This increase in ECM proteins leads to extensive fibrosis and progressive degeneration of normal pancreatic parenchyma [47]. However, that study shows another interesting finding, in which the PSCs expressing COL1A1 and FN1 upon IL-22 activation failed to express canonical activation markers such as alpha smooth muscle actin ( $\alpha \mathrm{SMA})$ and transforming growth factor $\beta$ (TGF $\beta$ ). Collectively, these reports establish the influence of smoking on adaptive immune mediators exacerbating (the complications of) $\mathrm{CP}$ pathology. Apart from T-cells, it is also expressed on pancreatic acinar cells and is regarded as a regulator of metabolic processes.

Similarly, a reduction in the number of $\mathrm{CD} 4^{+}$and $\mathrm{CD} 8^{+} \mathrm{T}$-cells in heavy drinkers $[56,57]$ and chronic ethanol-fed mice [58-60] demonstrates the negative effect of alcohol on adaptive immune function during AP. Long-term alcohol exposure alters the naïve T-cell differentiation profile, leading to the formation of the memory phenotype. However, chronic alcohol consumption, both in humans and mice, results in increased activation of $\mathrm{CD} 8^{+} \mathrm{T}$-cells, which could contribute to the induction of alcohol-induced CP [60]. Increased accumulation of memory T-cells with a concomitant decrease in naïve T-cells is associated with the onset of different inflammatory and age-related diseases [61, 62]. In addition to the total lymphocyte count, alcohol also alters the T-lymphocyte phenotype. Chronic alcohol exposure leads to increased T-cell activation-induced cell death, differentiates T-cells 
towards the memory phenotype and results in altered thymocyte development. These factors further affect B-cell development and maturation, resulting in increased levels of autoreactive antibodies [60], contributing to CP pathology. In addition, increased $\operatorname{IgA}$ and $\operatorname{IgM}$ levels both in heavy drinkers and mouse hybridomas treated with ethanol demonstrate the altered B-cell response, upon alcohol exposure $[56,63]$. The reason behind B-cell activation by alcohol is protein adducts and membrane lipid peroxidation by acetaldehyde, leading to an increased immunogenicity and autoimmune response [64]. Alcohol alone is not able to cause AP but acts as a metabolic stress factor, lowering the threshold of trypsin activation and increasing the susceptibility of pancreatic inflammation in the presence of other risk factors $[45,65,66]$. Furthermore, alcohol promotes anti-inflammatory effects by enhancing IL-10 release and inhibiting tumor necrosis factor-alpha (TNF- $\alpha$ ) production. However, its prolonged exposure increases gut permeability, resulting in the release of endotoxins and lipopolysaccharides (LPSs), leading to pancreatic cell necrosis during alcoholic CP $[67,68]$. In addition, necrotic cell death caused by alcohol during AP is a strong activator of the immune response and increases the severity of AP [46].

Multiple studies have exploited murine models to demonstrate the effects of alcohol in promoting pancreatic fibrosis in alcoholics and alcohol-induced acinar cell stress and altered immune function [69-71]. A study using an animal model for alcoholic chronic pancreatitis explains how alcohol promotes an anti-inflammatory environment during the recovery phase. After three consecutive AP episodes in alcohol-fed mice, there was an increased expression of anti-inflammatory mediators such as TGFB1, HIF1A and HIF3A. This overall anti-inflammatory stimulus promotes the tissue-specific expression of COL1A1, COL1A2 and FN1 in alcohol-fed mice, promoting disease in a pro-fibrotic direction. This was demonstrated by the striking differences in the pancreatic histology of mice subjected to AP either alone or in combination with chronic alcohol feeding. In comparison to the normal histology of pancreata from control (non-alcohol-fed) mice, the chronic alcohol-fed AP mice showed prominent necrotic areas with extensive fibrosis and calcification [69]. This model closely resembles the disease pathology observed in CP patients with heavy drinking history. Collectively, chronic alcohol exposure leads to pancreatic acinar cell stress, resulting in the release of stress-induced cytokines, which promote an anti-inflammatory environment. These anti-inflammatory mediators, such as IL-10 and TGFB1-producing T-cells and innate immune cells activate PSCs and fibroblasts, resulting in extensive fibrosis, a hallmark of CP. Unlike alcoholic and obstructive pancreatitis pathology, which exhibits inflamed and necrotic tissue, non-alcoholic duct destructive CP (NADDCP) shows ductal epithelial alterations, periductal-inflammation and fibrosis, nearly prompting the suspicion of pancreatic cancer. The major difference between alcoholic CP and NADDCP includes the diffused topography of lesions, the absence of calcification and cysts and the presence of mast cells, creating an inflammatory environment. The involvement of smoking and alcohol in shifting the inflammatory response from AP to chronic pancreatic inflammation, and the role of different molecular mediators, is shown in Figure 2.

PSCs are the key players in the fibrogenesis of CP. PSCs undergo hyper-proliferation and transformation to an activated state, resulting in the deposition of ECM components. Several studies have elucidated the role of ROS and soluble mediators from infiltrating immune cells in the activation of PSCs; however, few recent studies have shown the direct activation of PSCs upon exposure to cigarette smoke and alcohol. Like T- and B-cells, PSCs express nicotine acetylcholine receptors (nAChRs), which make them susceptible to activation by CSE. In the same study, it was found that nicotine-derived nitrosamine ketone (NNK), an active ingredient of CSE, either alone or in combination with alcohol, activates the $\alpha 7 \mathrm{nAChRs}$ on human PSCs, leading to an increase in their proliferation, migration and collagen-I synthesis [72]. A recent study demonstrated that proliferation and $\alpha$-SMA expression by human PSCs significantly increased upon exposure to nicotine. The nicotine-induced activation of human PSCs was associated with $\alpha 7 \mathrm{nAChR/Jak2-STAT3} \mathrm{axis-mediated} \mathrm{autophagic}$ induction [73]. Considering the heterogeneous cell types, defined spatial distribution and closely interactive physiology of the cellular components of the pancreas, it is tempting to speculate that in 
the face of an inflamed milieu and disruption of tissue architecture, there may be profound crosstalk between the injured acini, PSCs and the infiltrating immune cells. Indeed, a recent study demonstrated that upon alcohol-induced injury to the acini, proteases like kallikrein are released, which act on kininogens to produce bradykinin, that in turn results in activation of PSCs via Ca2+ signaling. This phenomenon can be further aggravated by the combination of alcohol and fatty acid ethyl esters (FAEEs) or bile acids that further lead to acini degeneration and the release of kallikrein via Ca2+ signaling [74].

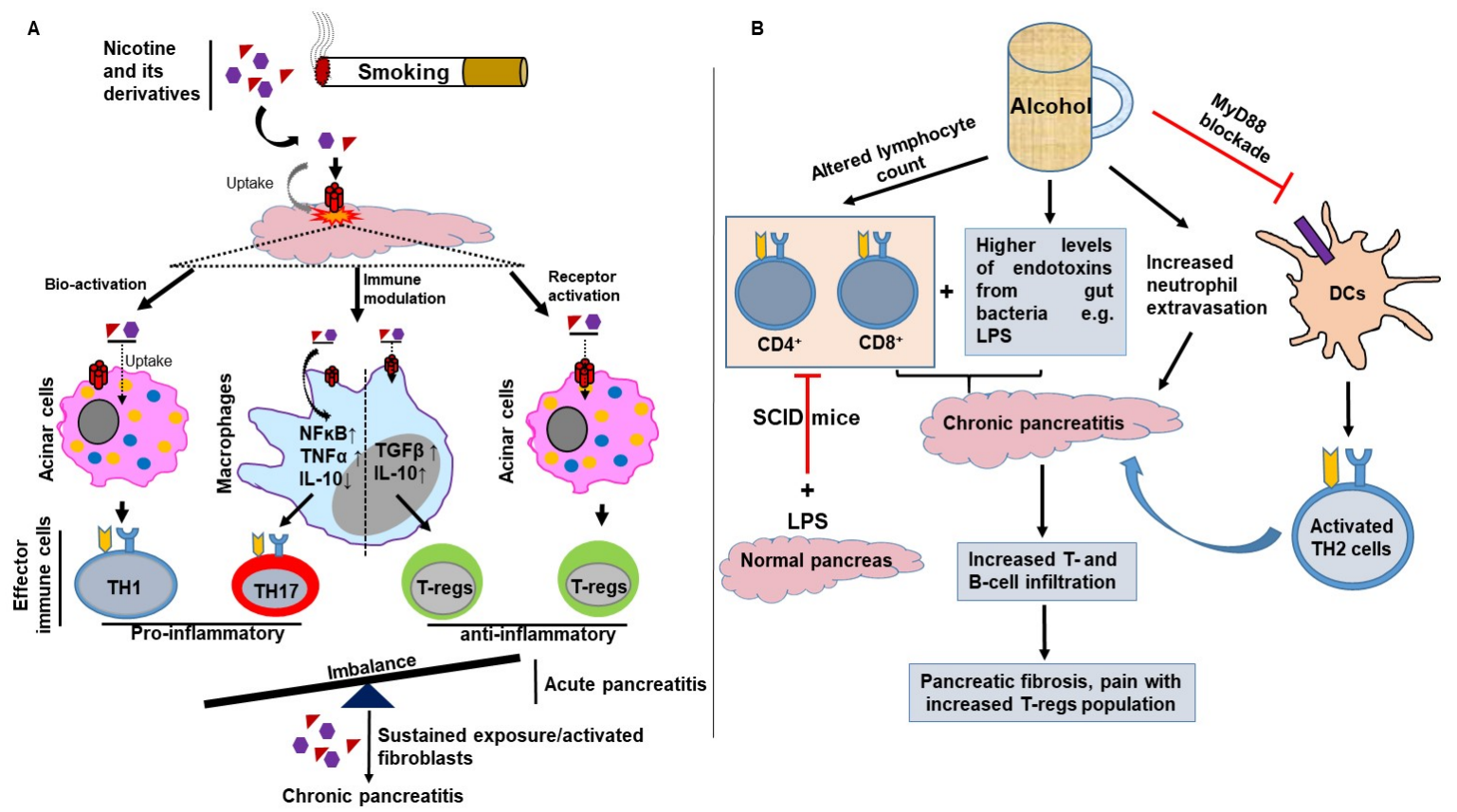

Figure 2. Adaptive immunity modulates smoke and alcohol-induced severity of AP. (A) Smoking contains nicotine and its derivatives. These smoking byproducts interact with their receptors, present on acinar and stellate cells, leading to the release of various chemokines, resulting in infiltration as well as activation of T- and B-lymphocytes, resulting in pancreatic inflammation. (B) Alcohol, on the other hand, negatively affects the adaptive immune function $\left(\mathrm{CD} 4^{+}\right.$and $\mathrm{CD} 8^{+} \mathrm{T}$ cell count) in AP. Unlike smoking, alcohol cannot independently induce pancreatitis but creates a predisposition towards the disease's progression by increasing susceptibility, in conjunction with the other risk factors. During CP, the pancreas is infiltrated by T- and B-cells, there is release of endotoxins and inflammatory components such as lipopolysaccharides (LPSs) due to alcohol-induced gut permeability, which further aggravates the disease pathology, resulting in pancreatic necrosis and fibrosis.

\section{Other Factors Influencing Adaptive Immunity in Pancreatitis}

In addition to smoking and alcohol, autoimmune pancreatitis, gallstones and genetic predisposition are the other common etiological factors that influence the incidence and severity of pancreatitis. All these factors show a differential impact on adaptive immune effector function driving disease severity. According to international consensus diagnostics criteria (ICDC), 2011 [75], autoimmune pancreatitis (AIP) is categorized into two major types, i.e., type I AIP and type II AIP. Type I AIP, also called lymphoplasmacytic sclerosing pancreatitis (LPSP), is characterized by increased IgG4 serum levels, whereas type II AIP, also known as idiopathic duct-centric pancreatitis (IDCP) includes the presence of granulocytic epithelial lesions (GEL) and the absence of IgG4 antibodies [75,76]. Narrowing of pancreatic ducts, enlargement of the pancreas and the presence of $\mathrm{CD} 4^{+}$and $\mathrm{CD} 8^{+} \mathrm{T}$-cells and IgG4-bearing plasma B-cells are among the major differentiating factors of AIP from AP. The presence of autoantibodies increased infiltration of TLR-7-positive M2 macrophages in pancreatic tissues, and an increase in B- and T-lymphocytes in type I AIP patients demonstrated the critical role of these immune mediators in disease pathogenesis [77-79]. Patients with AIP have elevated levels of serum 
autoantibodies against different self-antigens, such as carbonic anhydrase (CA) II [80,81], lactoferrin [82], amylase alpha2A [83], type IV collagen [84], heat-shock protein and plasminogen-binding protein [85]. These autoantibodies, along with IgG4, serve as diagnostic markers for AIP. An increased number of peripheral T-regs has also been shown to influence IgG4 antibodies in AIP [86]. The Th2 type immune response and T-regs have a critical role in type I AIP. Th2 response in AIP is primarily composed of B-cell differentiation and production of autoantibodies. Production of IgG4 and autoantibodies is further influenced by increased IL-10 secretion from T-regs, further enhancing AIP pathogenesis [87]. Furthermore, factors regulating cellular immune function, genetic polymorphism in the inhibitory receptor, as well as cytotoxic T-lymphocyte antigen 4 (CTLA4) also regulate AIP. CTLA4 polymorphism is associated with an enhanced risk of AIP relapse in patients and influences serum CTLA4 levels. Altogether, this study shows that genetic polymorphism in CTLA4 and its serum levels correlates positively in AIP patients.

Hereditary pancreatitis patients have $40 \%$ higher chances of progression to pancreatic cancer (PC) throughout their lifetime [34]. The major cause of hereditary pancreatitis is the mutation in cationic trypsinogen (PRSS1), serine protease inhibitor Kazal 1 (SPINK1) and cystic fibrosis transmembrane conductance regulator (CFTR) genes [88]. These genes, in one way or the other, are involved in trypsinogen activation or trypsin inhibition, which are directly or indirectly involved in pancreatic acinar cell injury [89]. These genes play a significant role in progressing the disease from AP to CP. Along with immunological factors, such as infiltrating $\mathrm{CD}^{+}$and $\mathrm{CD} 8^{+} \mathrm{T}$ lymphocytes, polymorphism in the major histocompatibility complex (MHC) has also been shown to play a significant role in $\mathrm{CP}$ pathogenesis [90-94]. Compared to the healthy controls, the HLADRB1*0401 allele, encoding unique motif ${ }^{70} \mathrm{QKRAA}^{74}$, is significantly expressed in CP patients. A study showed that expression of the HLADRB1*0401 allele, along with other hereditary (PRSS1, SPINK1, CFTR) mutations and environmental factors such as chronic smoke exposure and alcohol abuse, could further predispose patients towards CP [95]. Further, pancreatic immune cell profiling revealed the differences between hereditary and idiopathic $\mathrm{CP}$. In the case of idiopathic $\mathrm{CP}$, there was an increased frequency of $\mathrm{CD} 68^{+}$ macrophages, whereas $\mathrm{CD}^{+} \mathrm{T}$-cells were significantly high in hereditary $\mathrm{CP}$, suggesting that the difference between innate and adaptive immune responses in hereditary and idiopathic $\mathrm{CP}$ indicates differential disease pathologies [96]. Gallstones are also among the major causes of acute pancreatitis. Gallstone-mediated pancreatic duct obstruction leads to pancreatic injury, resulting in gallstone-induced AP. Initial pathophysiological events in gallstone-induced pancreatitis affect acinar cells, causing strong acute phase response. A genetic predisposition for gallstone formation also increases the risk of AP episodes $[97,98]$.

\section{Impact of Targeting the Adaptive Immune Arm in Pancreatitis}

As the primary event during the AP episode is the robust inflammatory response, therapeutic targeting using anti-inflammatory agents remains an area of interest. Various anti-inflammatory agents, such as Sivelestat, Glycyrrhizine, Rofecoxib, Flavocoxid and Lisinopril, have been studied in AP therapy (Figure 3). The detailed mechanisms of action targeting both the innate and adaptive immune arms by these agents in AP have been discussed elsewhere [99]. Among different anti-inflammatory agents, IL-6 inhibitors have showed promise towards AP therapy. The IL-6 inhibitor Tocilizumab, used as an anti-inflammatory agent in different inflammatory disorders, has been shown to alter the severity of AP in animal models. Major contributing factors in $\mathrm{CP}$ pathology are pancreatic tissue fibrosis and abundantly infiltrated T-lymphocytes. Targeting T-lymphocytes has proven to reduce the severity of disease in animal models [14]. Similarly, macrophages and PSCs are the predominant inducers of fibrosis in CP. Alternatively, activated macrophages interact with PSCs by IL-4/IL-13 signaling, and pharmacological targeting of IL4/IL13 using blocking peptides showed reduced fibrosis in CP animal models [13]. Using natural products, such as apigenin, rhein and tocotrienol-rich fraction (TRF) from palm oil, for targeting PSCs shows promise in reversing fibrosis in CP [100-102]. Some reports demonstrate that recovering T-reg loss and restoring IL-10 levels during CP suppress 
$\mathrm{CD}^{+} \mathrm{T}$-cell over-activation and hence reduces the severity of CP $[39,86]$. Apart from targeting, the major area of focus in pancreatitis research at present is finding a robust, reliable and promising diagnostic marker for determining the severity of AP and MOF driven by AP. The systemic alteration of $\mathrm{CD}^{+}$T-lymphocyte and B-lymphocytes during the early phase of AP, indicating persistent MOF [29], and increased circulating levels of CD4 $4^{+}$T-cell cytokines such as IL22 [55], TGF $\beta$ and IL10 during acute and chronic pancreatitis, establishes the utility of adaptive immune effectors as the predictors of disease severity in the context of different etiological contributors. ONe study has demonstrated the significant differences between the type of circulating immune cells in case of RAP, CP and pancreatic cancer. This retrospective analysis of human serum samples from control, RAP, CP and PC patients showed a unique immune signature that can serve as a novel diagnostic marker as well as a disease predictor in various pancreatic pathologies [103]. A recent study by Zhang et al. utilized innate and adaptive immune cells as a predictor of disease severity. The study showed a significant increase in peripheral CD14 ${ }^{\mathrm{hi}+} \mathrm{CD} 16^{-}$monocytes within $48 \mathrm{~h}$ of AP onset. This increase in peripheral $\mathrm{CD} 14^{\mathrm{hi}+} \mathrm{CD} 16^{-}$monocytes was followed by a concomitant reduction in HLA-DR expression, as well as $\mathrm{CD} 4^{+} \mathrm{T}$-cells. This difference was more profound in the case of SAP; therefore, both of these factors in combination can be used as a predictor of AP severity [104].

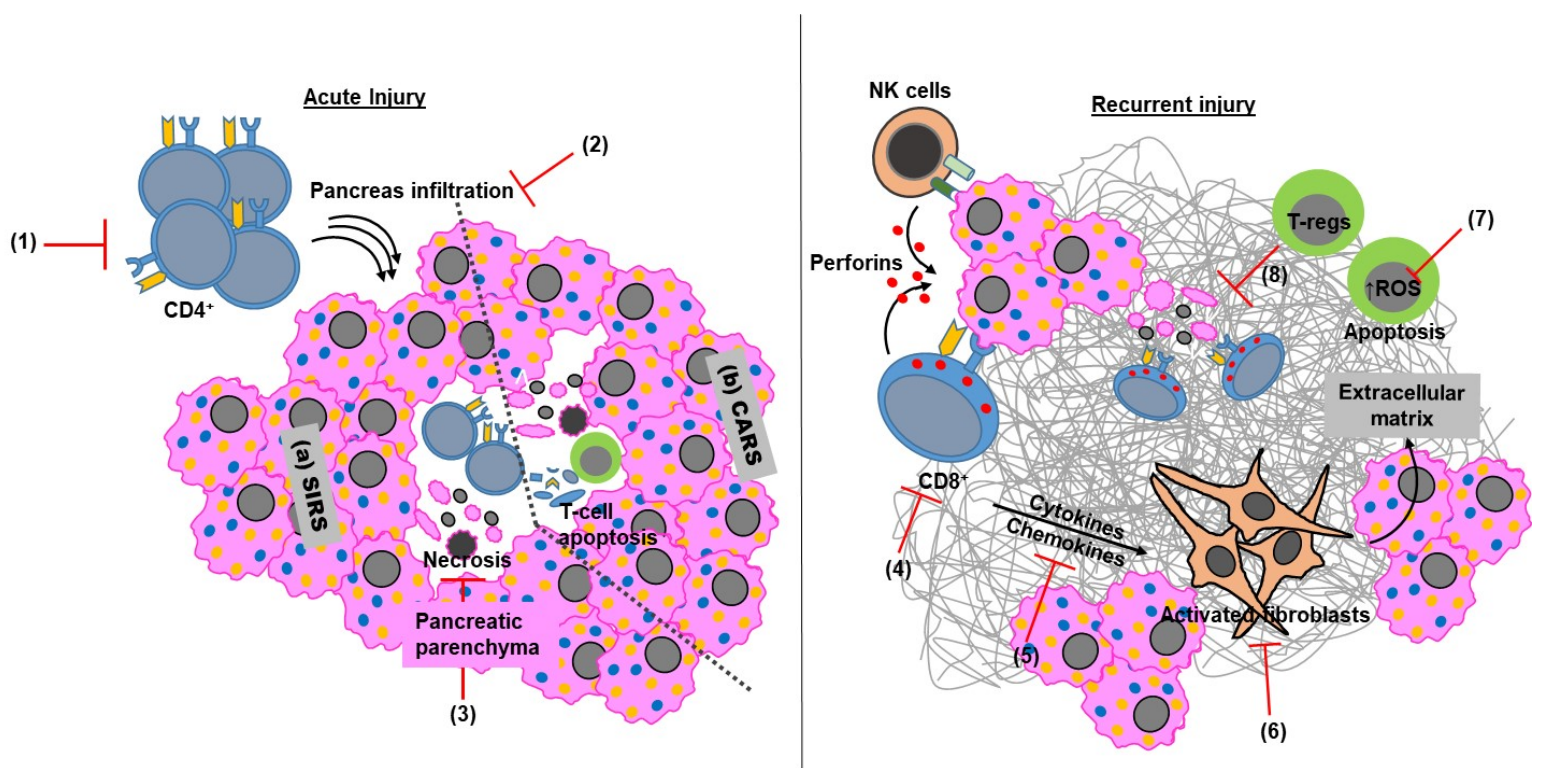

Figure 3. Targeting adaptive immune mediators during acute and chronic pancreatitis. Genetic ablation using athymic or T-lymphocyte-deficient mice (1) or reduced infiltration (2) of T-lymphocytes decreases the severity of acute pancreatitis. Therefore, targeting infiltrating T-lymphocytes (2) and tissue necrosis (3) is a promising strategy to reduce the acute phase responses like (a) SIRS or (b) CARS in AP. Recurrent pancreatic injury causes irreversible damage, which is effectively curtailed by targeting cytotoxic mediators (4 and 5). Targeting the inflammatory stimulus (6) by these adaptive and innate immune cells reduces pancreatic stellate cell activation (7), leading to the maintenance of pancreatic parenchyma and decreased ECM deposition. Reducing the T-reg apoptosis (8) by targeting intracellular ROS is also a promising strategy in reducing acinar cell apoptosis (9), inflammation and the maintenance of pancreatic parenchyma. SIRS; systemic immunological response syndrome. CARS; compensatory anti-inflammatory response syndrome.

\section{Conclusions}

The clinical progression of pancreatitis depends on both the extent of pancreatic tissue damage and the degree of the systemic immune response. Secondary factors, such as infections or vascular permeability, are also implicated in sepsis or MOF during pancreatic insult. Typically, the infiltration of immune cells is a protective response generated by the immune system to curtail the pancreatic damage, 
but as the disease progresses, the overwhelming anti-inflammatory response leads to a systemic immunosuppressive environment, leading to the onset of secondary complications. The adaptive immune arm plays a significant role in this entire cascade. During the initial episodes, high infiltration of T- $\left(\mathrm{CD} 4^{+}\right.$and $\left.\mathrm{CD}^{+}\right)$and B-cells facilitate the recovery from acinar cell damage by clearing the apoptotic cells, reducing the inflammation and restoring the immunosuppressive environment. The situation becomes complicated when the onset of AP leads to immune syndromes such as SIRS and CARS, resulting in fatal outcomes. During $\mathrm{CP}, \mathrm{CD} 8^{+}$and NKT-cells are the major players inducing cell-mediated cytotoxicity. Their exclusive role in $\mathrm{CP}$ can be further supported by their abundance in the fibrotic tissue. It will be interesting to know how adaptive immune cell repertoire changes with different therapeutic interventions and how it helps in resolving the onset as well as the severity of the disease.

Author Contributions: R.B., C.T. and K.G. wrote the manuscript, and S.S., S.K.B. and S.K. edited and revised the manuscript. All authors have approved the manuscript.

Funding: This work: in parts, was supported by funding from the National Institute of Health (PO1 CA 217798, UO1 CA210240, UO1 CA200466, R01 CA183459, RO1 CA 195586, RO1 CA206444, R21 AA 026428, and RO1 CA228524).

Conflicts of Interest: S.K.B. is co-founder of Sanguine Diagnostics and Therapeutics, Inc. Other authors have no conflicts of interest to declare.

\section{References}

1. Sarles, H.; Sarles, J.C.; Muratore, R.; Guien, C. Chronic inflammatory sclerosis of the pancreas-an autonomous pancreatic disease? Am. J. Dig. Dis. 1961, 6, 688-698. [CrossRef] [PubMed]

2. Sandoval, D.; Gukovskaya, A.; Reavey, P.; Gukovsky, S.; Sisk, A.; Braquet, P.; Pandol, S.J.; Poucell-Hatton, S. The role of neutrophils and platelet-activating factor in mediating experimental pancreatitis. Gastroenterology 1996, 111, 1081-1091. [CrossRef]

3. Gukovskaya, A.S.; Vaquero, E.; Zaninovic, V.; Gorelick, F.S.; Lusis, A.J.; Brennan, M.L.; Holland, S.; Pandol, S.J. Neutrophils and NADPH oxidase mediate intrapancreatic trypsin activation in murine experimental acute pancreatitis. Gastroenterology 2002, 122, 974-984. [CrossRef] [PubMed]

4. Gukovskaya, A.S.; Gukovsky, I.; Zaninovic, V.; Song, M.; Sandoval, D.; Gukovsky, S.; Pandol, S.J. Pancreatic acinar cells produce, release, and respond to tumor necrosis factor-alpha. Role in regulating cell death and pancreatitis. J. Clin. Invest. 1997, 100, 1853-1862. [CrossRef] [PubMed]

5. Bhatia, M.; Brady, M.; Shokuhi, S.; Christmas, S.; Neoptolemos, J.P.; Slavin, J. Inflammatory mediators in acute pancreatitis. J. Pathol. 2000, 190, 117-125. [CrossRef]

6. Zhang, H.; Neuhofer, P.; Song, L.; Rabe, B.; Lesina, M.; Kurkowski, M.U.; Treiber, M.; Wartmann, T.; Regner, S.; Thorlacius, H.; et al. IL-6 trans-signaling promotes pancreatitis-associated lung injury and lethality. J. Clin. Invest. 2013, 123, 1019-1031. [CrossRef]

7. Takeyama, Y.; Nishikawa, J.; Ueda, T.; Hori, Y.; Yamamoto, M.; Kuroda, Y. Involvement of peritoneal macrophage in the induction of cytotoxicity due to apoptosis in ascitic fluid associated with severe acute pancreatitis. J. Surg. Res. 1999, 82, 163-171. [CrossRef]

8. Xue, J.; Sharma, V.; Habtezion, A. Immune cells and immune-based therapy in pancreatitis. Immunol. Res. 2014, 58, 378-386. [CrossRef]

9. Habtezion, A. Inflammation in acute and chronic pancreatitis. Curr. Opin. Gastroenterol. 2015, 31, $395-399$. [CrossRef]

10. Bedrosian, A.S.; Nguyen, A.H.; Hackman, M.; Connolly, M.K.; Malhotra, A.; Ibrahim, J.; Cieza-Rubio, N.E.; Henning, J.R.; Barilla, R.; Rehman, A.; et al. Dendritic cells promote pancreatic viability in mice with acute pancreatitis. Gastroenterology 2011, 141, 1915-1926. [CrossRef]

11. Zheng, L.; Xue, J.; Jaffee, E.M.; Habtezion, A. Role of immune cells and immune-based therapies in pancreatitis and pancreatic ductal adenocarcinoma. Gastroenterology 2013, 144, 1230-1240. [CrossRef] [PubMed]

12. Yadav, D.; Lowenfels, A.B. The epidemiology of pancreatitis and pancreatic cancer. Gastroenterology 2013, 144, 1252-1261. [CrossRef] [PubMed] 
13. Xue, J.; Sharma, V.; Hsieh, M.H.; Chawla, A.; Murali, R.; Pandol, S.J.; Habtezion, A. Alternatively activated macrophages promote pancreatic fibrosis in chronic pancreatitis. Nat. Commun. 2015, 6, 7158. [CrossRef] [PubMed]

14. Demols, A.; Le Moine, O.; Desalle, F.; Quertinmont, E.; Van Laethem, J.L.; Deviere, J. CD4(+)T cells play an important role in acute experimental pancreatitis in mice. Gastroenterology 2000, 118, 582-590. [CrossRef]

15. Schmitz-Winnenthal, H.; Pietsch, D.H.; Schimmack, S.; Bonertz, A.; Udonta, F.; Ge, Y.; Galindo, L.; Specht, S.; Volk, C.; Zgraggen, K.; et al. Chronic pancreatitis is associated with disease-specific regulatory T-cell responses. Gastroenterology 2010, 138, 1178-1188. [CrossRef] [PubMed]

16. Emmrich, J.; Weber, I.; Nausch, M.; Sparmann, G.; Koch, K.; Seyfarth, M.; Lohr, M.; Liebe, S. Immunohistochemical characterization of the pancreatic cellular infiltrate in normal pancreas, chronic pancreatitis and pancreatic carcinoma. Digestion 1998, 59, 192-198. [CrossRef]

17. Pietruczuk, M.; Dabrowska, M.I.; Wereszczynska-Siemiatkowska, U.; Dabrowski, A. Alteration of peripheral blood lymphocyte subsets in acute pancreatitis. World J. Gastroenterol. 2006, 12, 5344-5351. [CrossRef]

18. Curley, P.J.; McMahon, M.J.; Lancaster, F.; Banks, R.E.; Barclay, G.R.; Shefta, J.; Boylston, A.W.; Whicher, J.T. Reduction in circulating levels of CD4-positive lymphocytes in acute pancreatitis: Relationship to endotoxin, interleukin 6 and disease severity. Br. J. Surg. 1993, 80, 1312-1315. [CrossRef]

19. Pezzilli, R.; Billi, P.; Beltrandi, E.; Maldini, M.; Mancini, R.; Morselli Labate, A.M.; Miglioli, M. Circulating lymphocyte subsets in human acute pancreatitis. Pancreas 1995, 11, 95-100. [CrossRef]

20. Kempuraj, D.; Twait, E.C.; Williard, D.E.; Yuan, Z.; Meyerholz, D.K.; Samuel, I. The novel cytokine interleukin-33 activates acinar cell proinflammatory pathways and induces acute pancreatic inflammation in mice. PLoS ONE 2013, 8, e56866. [CrossRef]

21. Uehara, S.; Gothoh, K.; Handa, H.; Tomita, H.; Tomita, Y. Immune function in patients with acute pancreatitis. J. Gastroenterol. Hepatol. 2003, 18, 363-370. [CrossRef] [PubMed]

22. Curley, P.; Nestor, M.; Collins, K.; Saporoschetz, I.; Mendez, M.; Mannick, J.A.; Rodrick, M.L. Decreased interleukin-2 production in murine acute pancreatitis: Potential for immunomodulation. Gastroenterology 1996, 110, 583-588. [CrossRef] [PubMed]

23. Oiva, J.; Mustonen, H.; Kylanpaa, M.L.; Kyhala, L.; Kuuliala, K.; Siitonen, S.; Kemppainen, E.; Puolakkainen, P.; Repo, H. Acute pancreatitis with organ dysfunction associates with abnormal blood lymphocyte signaling: Controlled laboratory study. Crit. Care 2010, 14, R207. [CrossRef] [PubMed]

24. Mylona, V.; Koussoulas, V.; Tzivras, D.; Makrygiannis, E.; Georgopoulou, P.; Koratzanis, G.; Giamarellos-Bourboulis, E.J.; Tzivras, M.D. Changes in adaptive and innate immunity in patients with acute pancreatitis and systemic inflammatory response syndrome. Pancreatology 2011, 11, 475-481. [CrossRef] [PubMed]

25. Inman, K.S.; Francis, A.A.; Murray, N.R. Complex role for the immune system in initiation and progression of pancreatic cancer. World J. Gastroenterol 2014, 20, 11160-11181. [CrossRef] [PubMed]

26. Zerem, E. Treatment of severe acute pancreatitis and its complications. World J. Gastroenterol. 2014, 20, 13879-13892. [CrossRef]

27. Beger, H.G.; Bittner, R.; Block, S.; Buchler, M. Bacterial contamination of pancreatic necrosis. A prospective clinical study. Gastroenterology 1986, 91, 433-438. [CrossRef]

28. Banks, P.A.; Bollen, T.L.; Dervenis, C.; Gooszen, H.G.; Johnson, C.D.; Sarr, M.G.; Tsiotos, G.G.; Vege, S.S. Classification of acute pancreatitis-2012: Revision of the Atlanta classification and definitions by international consensus. Gut 2013, 62, 102-111. [CrossRef]

29. Yang, Z.; Zhang, Y.; Dong, L.; Yang, C.; Gou, S.; Yin, T.; Wu, H.; Wang, C. The Reduction of Peripheral Blood CD4+ T Cell Indicates Persistent Organ Failure in Acute Pancreatitis. PLoS ONE 2015, 10, e0125529. [CrossRef]

30. Shi, C.; Hou, C.; Zhu, X.; Peng, Y.; Guo, F.; Zhang, K.; Huang, D.; Li, Q.; Miao, Y. New Predictor of Organ Failure in Acute Pancreatitis: CD4+ T Lymphocytes and CD19+ B Lymphocytes. Biomed. Res. Int. 2018, 2018, 1012584. [CrossRef]

31. Xue, J.; Nguyen, D.T.; Habtezion, A. Aryl hydrocarbon receptor regulates pancreatic IL-22 production and protects mice from acute pancreatitis. Gastroenterology 2012, 143, 1670-1680. [CrossRef] [PubMed]

32. Qiu, L.; Zhou, Y.; Yu, Q.; Yu, J.; Li, Q.; Sun, R. Decreased levels of regulatory B cells in patients with acute pancreatitis: Association with the severity of the disease. Oncotarget 2018, 9, 36067-36082. [CrossRef] [PubMed] 
33. McKay, C.J.; Glen, P.; McMillan, D.C. Chronic inflammation and pancreatic cancer. Best Pract. Res. Clin. Gastroenterol. 2008, 22, 65-73. [CrossRef] [PubMed]

34. Vitone, L.J.; Greenhalf, W.; Howes, N.R.; Neoptolemos, J.P. Hereditary pancreatitis and secondary screening for early pancreatic cancer. Rocz. Akad. Med. Bialymst. 2005, 50, 73-84. [PubMed]

35. Ebert, M.P.; Ademmer, K.; Muller-Ostermeyer, F.; Friess, H.; Buchler, M.W.; Schubert, W.; Malfertheiner, P. CD8+CD103+ T cells analogous to intestinal intraepithelial lymphocytes infiltrate the pancreas in chronic pancreatitis. Am. J. Gastroenterol. 1998, 93, 2141-2147. [CrossRef]

36. Hunger, R.E.; Mueller, C.; Z'Graggen, K.; Friess, H.; Buchler, M.W. Cytotoxic cells are activated in cellular infiltrates of alcoholic chronic pancreatitis. Gastroenterology 1997, 112, 1656-1663. [CrossRef]

37. Yamada, T.; Hashimoto, T.; Sogawa, M.; Kobayashi, S.; Kaneda, K.; Nakamura, S.; Kuno, A.; Sano, H.; Ando, T.; Kobayashi, S.; et al. Role of T cells in development of chronic pancreatitis in male Wistar Bonn/Kobori rats: Effects of tacrolimus. Am. J. Physiol. Gastrointest Liver Physiol. 2001, 281, G1397-1404. [CrossRef]

38. Gansauge, F.; Gansauge, S.; Eh, M.; Schlosser, W.; Ramadani, M.; Kern, P.; Beger, H.G. Distributional and functional alterations of immunocompetent peripheral blood lymphocytes in patients with chronic pancreatitis. Ann. Surg. 2001, 233, 365-370. [CrossRef]

39. Chen, L.; Ma, C.; Bian, Y.; Li, J.; Wang, T.; Su, L.; Lu, J. Hydrogen Treatment Protects Mice Against Chronic Pancreatitis by Restoring Regulatory T Cells Loss. Cell Physiol. Biochem. 2017, 44, 2005-2016. [CrossRef]

40. Grundsten, M.; Liu, G.Z.; Permert, J.; Hjelmstrom, P.; Tsai, J.A. Increased central memory T cells in patients with chronic pancreatitis. Pancreatology 2005, 5, 177-182. [CrossRef]

41. Ochi, A.; Nguyen, A.H.; Bedrosian, A.S.; Mushlin, H.M.; Zarbakhsh, S.; Barilla, R.; Zambirinis, C.P.; Fallon, N.C.; Rehman, A.; Pylayeva-Gupta, Y.; et al. MyD88 inhibition amplifies dendritic cell capacity to promote pancreatic carcinogenesis via Th2 cells. J. Exp. Med. 2012, 209, 1671-1687. [CrossRef] [PubMed]

42. Ammann, R.W.; Muellhaupt, B.; Meyenberger, C.; Heitz, P.U. Alcoholic nonprogressive chronic pancreatitis: Prospective long-term study of a large cohort with alcoholic acute pancreatitis (1976-1992). Pancreas 1994, 9 , 365-373. [CrossRef] [PubMed]

43. Lankisch, P.G.; Breuer, N.; Bruns, A.; Weber-Dany, B.; Lowenfels, A.B.; Maisonneuve, P. Natural history of acute pancreatitis: A long-term population-based study. Am. J. Gastroenterol. 2009, 104, 2797-2805. [CrossRef] [PubMed]

44. Lugea, A.; Gerloff, A.; Su, H.Y.; Xu, Z.; Go, A.; Hu, C.; French, S.W.; Wilson, J.S.; Apte, M.V.; Waldron, R.T.; et al. The Combination of Alcohol and Cigarette Smoke Induces Endoplasmic Reticulum Stress and Cell Death in Pancreatic Acinar Cells. Gastroenterology 2017, 153, 1674-1686. [CrossRef] [PubMed]

45. Sahin-Toth, M.; Hegyi, P. Smoking and Drinking Synergize in Pancreatitis: Multiple Hits on Multiple Targets. Gastroenterology 2017, 153, 1479-1481. [CrossRef]

46. Yadav, D.; Whitcomb, D.C. The role of alcohol and smoking in pancreatitis. Nat. Rev. Gastroenterol. Hepatol. 2010, 7, 131-145. [CrossRef]

47. Kumar, S.; Batra, S.K. Interleukin-22 Connects Smoking and Pancreatic Fibrosis During Chronic Pancreatitis. Gastroenterology 2016, 151, 1067-1070. [CrossRef]

48. Galitovskiy, V.; Qian, J.; Chernyavsky, A.I.; Marchenko, S.; Gindi, V.; Edwards, R.A.; Grando, S.A. Cytokine-induced alterations of alpha7 nicotinic receptor in colonic CD4 T cells mediate dichotomous response to nicotine in murine models of Th1/Th17- versus Th2-mediated colitis. J. Immunol. 2011, 187, 2677-2687. [CrossRef]

49. Skok, M.V.; Kalashnik, E.N.; Koval, L.N.; Tsetlin, V.I.; Utkin, Y.N.; Changeux, J.P.; Grailhe, R. Functional nicotinic acetylcholine receptors are expressed in B lymphocyte-derived cell lines. Mol. Pharmacol. 2003, 64, 885-889. [CrossRef]

50. Arnson, Y.; Shoenfeld, Y.; Amital, H. Effects of tobacco smoke on immunity, inflammation and autoimmunity. J. Autoimmun. 2010, 34, J258-265. [CrossRef]

51. Kalra, R.; Singh, S.P.; Savage, S.M.; Finch, G.L.; Sopori, M.L. Effects of cigarette smoke on immune response: Chronic exposure to cigarette smoke impairs antigen-mediated signaling in T cells and depletes IP3-sensitive $\mathrm{Ca}(2+)$ stores. J. Pharmacol. Exp. Ther. 2000, 293, 166-171. [PubMed]

52. Maeno, T.; Houghton, A.M.; Quintero, P.A.; Grumelli, S.; Owen, C.A.; Shapiro, S.D. CD8+ T Cells are required for inflammation and destruction in cigarette smoke-induced emphysema in mice. J. Immunol. 2007, 178, 8090-8096. [CrossRef] [PubMed]

53. Muto, H.; Takizawa, Y. Dioxins in cigarette smoke. Arch. Environ. Health 1989, 44, 171-174. [CrossRef] [PubMed] 
54. Stedman, R.L. The chemical composition of tobacco and tobacco smoke. Chem. Rev. 1968, 68, $153-207$. [CrossRef] [PubMed]

55. Xue, J.; Zhao, Q.; Sharma, V.; Nguyen, L.P.; Lee, Y.N.; Pham, K.L.; Edderkaoui, M.; Pandol, S.J.; Park, W.; Habtezion, A. Aryl Hydrocarbon Receptor Ligands in Cigarette Smoke Induce Production of Interleukin-22 to Promote Pancreatic Fibrosis in Models of Chronic Pancreatitis. Gastroenterology 2016, 151, 1206-1217. [CrossRef] [PubMed]

56. Mili, F.; Flanders, W.D.; Boring, J.R.; Annest, J.L.; DeStefano, F. The associations of alcohol drinking and drinking cessation to measures of the immune system in middle-aged men. Alcohol Clin. Exp. Res. 1992, 16, 688-694. [CrossRef]

57. Gheorghiu, M.; Bara, C.; Pasarica, D.; Brasoveanu, L.; Bleotu, C.; Toparceanu, F.; Trandafir, T.; Diaconu, C.C. Ethanol-induced dysfunction of hepatocytes and leukocytes in patients without liver failure. Roum. Arch. Microbiol. Immunol. 2004, 63, 5-33. [PubMed]

58. Boyadjieva, N.I.; Dokur, M.; Advis, J.P.; Meadows, G.G.; Sarkar, D.K. Beta-endorphin modulation of lymphocyte proliferation: Effects of ethanol. Alcohol Clin. Exp. Res. 2002, 26, 1719-1727. [CrossRef]

59. Slukvin, II.; Jerrells, T.R. Different pathways of in vitro ethanol-induced apoptosis in thymocytes and splenic T and B lymphocytes. Immunopharmacology 1995, 31, 43-57. [CrossRef]

60. Pasala, S.; Barr, T.; Messaoudi, I. Impact of Alcohol Abuse on the Adaptive Immune System. Alcohol Res. 2015, 37, 185-197.

61. Hakim, F.T.; Gress, R.E. Immunosenescence: Deficits in adaptive immunity in the elderly. Tissue Antigens 2007, 70, 179-189. [CrossRef] [PubMed]

62. Chou, J.P.; Effros, R.B. T cell replicative senescence in human aging. Curr. Pharm. Des. 2013, 19, 1680-1698. [CrossRef] [PubMed]

63. Muhlbauer, E.; Karsten, U.; Rottmann, M.; Rommelspacher, H. Impaired immunoglobulin M production by incubation of hybridoma cells with ethanol. Alcohol 2001, 24, 179-187. [CrossRef]

64. Thiele, G.M.; Duryee, M.J.; Willis, M.S.; Tuma, D.J.; Radio, S.J.; Hunter, C.D.; Schaffert, C.S.; Klassen, L.W. Autoimmune hepatitis induced by syngeneic liver cytosolic proteins biotransformed by alcohol metabolites. Alcohol Clin. Exp. Res. 2010, 34, 2126-2136. [CrossRef] [PubMed]

65. Clemens, D.L.; Schneider, K.J.; Arkfeld, C.K.; Grode, J.R.; Wells, M.A.; Singh, S. Alcoholic pancreatitis: New insights into the pathogenesis and treatment. World J. Gastrointest. Pathophysiol. 2016, 7, 48-58. [CrossRef] [PubMed]

66. Chowdhury, P.; Gupta, P. Pathophysiology of alcoholic pancreatitis: An overview. World J. Gastroenterol. 2006, 12, 7421-7427. [CrossRef] [PubMed]

67. Vonlaufen, A.; Xu, Z.; Daniel, B.; Kumar, R.K.; Pirola, R.; Wilson, J.; Apte, M.V. Bacterial endotoxin: A trigger factor for alcoholic pancreatitis? Evidence from a novel, physiologically relevant animal model. Gastroenterology 2007, 133, 1293-1303. [CrossRef]

68. Vonlaufen, A.; Phillips, P.A.; Xu, Z.; Zhang, X.; Yang, L.; Pirola, R.C.; Wilson, J.S.; Apte, M.V. Withdrawal of alcohol promotes regression while continued alcohol intake promotes persistence of LPS-induced pancreatic injury in alcohol-fed rats. Gut 2011, 60, 238-246. [CrossRef]

69. Deng, X.; Wang, L.; Elm, M.S.; Gabazadeh, D.; Diorio, G.J.; Eagon, P.K.; Whitcomb, D.C. Chronic alcohol consumption accelerates fibrosis in response to cerulein-induced pancreatitis in rats. Am. J. Pathol. 2005, 166, 93-106. [CrossRef]

70. Gukovsky, I.; Lugea, A.; Shahsahebi, M.; Cheng, J.H.; Hong, P.P.; Jung, Y.J.; Deng, Q.G.; French, B.A.; Lungo, W.; French, S.W.; et al. A rat model reproducing key pathological responses of alcoholic chronic pancreatitis. Am. J. Physiol. Gastrointest. Liver Physiol. 2008, 294, G68-79. [CrossRef]

71. Perides, G.; Tao, X.; West, N.; Sharma, A.; Steer, M.L. A mouse model of ethanol dependent pancreatic fibrosis. Gut 2005, 54, 1461-1467. [CrossRef] [PubMed]

72. Lee, A.T.; Xu, Z.; Pothula, S.P.; Patel, M.B.; Pirola, R.C.; Wilson, J.S.; Apte, M.V. Alcohol and cigarette smoke components activate human pancreatic stellate cells: Implications for the progression of chronic pancreatitis. Alcohol Clin. Exp. Res. 2015, 39, 2123-2133. [CrossRef] [PubMed]

73. Li, Z.; Zhang, X.; Jin, T.; Hao, J. Nicotine promotes activation of human pancreatic stellate cells through inducing autophagy via alpha7nAChR-mediated JAK2/STAT3 signaling pathway. Life Sci. 2020, 243, 117301. [CrossRef] [PubMed] 
74. Gryshchenko, O.; Gerasimenko, J.V.; Gerasimenko, O.V.; Petersen, O.H. Calcium signalling in pancreatic stellate cells: Mechanisms and potential roles. Cell Calcium 2016, 59, 140-144. [CrossRef] [PubMed]

75. Shimosegawa, T.; Chari, S.T.; Frulloni, L.; Kamisawa, T.; Kawa, S.; Mino-Kenudson, M.; Kim, M.H.; Kloppel, G.; Lerch, M.M.; Lohr, M.; et al. International consensus diagnostic criteria for autoimmune pancreatitis: Guidelines of the International Association of Pancreatology. Pancreas 2011, 40, 352-358. [CrossRef]

76. Fritz, S.; Bergmann, F.; Grenacher, L.; Sgroi, M.; Hinz, U.; Hackert, T.; Buchler, M.W.; Werner, J. Diagnosis and treatment of autoimmune pancreatitis types 1 and 2. Br. J. Surg. 2014, 101, 1257-1265. [CrossRef]

77. Watanabe, T.; Yamashita, K.; Fujikawa, S.; Sakurai, T.; Kudo, M.; Shiokawa, M.; Kodama, Y.; Uchida, K.; Okazaki, K.; Chiba, T. Involvement of activation of toll-like receptors and nucleotide-binding oligomerization domain-like receptors in enhanced IgG4 responses in autoimmune pancreatitis. Arthritis Rheum. 2012, 64, 914-924. [CrossRef]

78. Watanabe, T.; Yamashita, K.; Sakurai, T.; Kudo, M.; Shiokawa, M.; Uza, N.; Kodama, Y.; Uchida, K.; Okazaki, K.; Chiba, T. Toll-like receptor activation in basophils contributes to the development of IgG4-related disease. J. Gastroenterol. 2013, 48, 247-253. [CrossRef]

79. Fukui, Y.; Uchida, K.; Sakaguchi, Y.; Fukui, T.; Nishio, A.; Shikata, N.; Sakaida, N.; Uemura, Y.; Satoi, S.; Okazaki, K. Possible involvement of Toll-like receptor 7 in the development of type 1 autoimmune pancreatitis. J. Gastroenterol. 2015, 50, 435-444. [CrossRef]

80. Nishi, H.; Tojo, A.; Onozato, M.L.; Jimbo, R.; Nangaku, M.; Uozaki, H.; Hirano, K.; Isayama, H.; Omata, M.; Kaname, S.; et al. Anti-carbonic anhydrase II antibody in autoimmune pancreatitis and tubulointerstitial nephritis. Nephrol. Dial. Transplant. 2007, 22, 1273-1275. [CrossRef]

81. Okazaki, K.; Uchida, K.; Ohana, M.; Nakase, H.; Uose, S.; Inai, M.; Matsushima, Y.; Katamura, K.; Ohmori, K.; Chiba, T. Autoimmune-related pancreatitis is associated with autoantibodies and a Th1/Th2-type cellular immune response. Gastroenterology 2000, 118, 573-581. [CrossRef]

82. Cai, O.; Tan, S. From Pathogenesis, Clinical Manifestation, and Diagnosis to Treatment: An Overview on Autoimmune Pancreatitis. Gastroenterol. Res. Pract. 2017, 2017, 3246459. [CrossRef] [PubMed]

83. Endo, T.; Takizawa, S.; Tanaka, S.; Takahashi, M.; Fujii, H.; Kamisawa, T.; Kobayashi, T. Amylase alpha-2A autoantibodies: Novel marker of autoimmune pancreatitis and fulminant type 1 diabetes. Diabetes 2009, 58, 732-737. [CrossRef] [PubMed]

84. Liu, Q.C.; Dong, F.; Pan, J.F.; Zhuang, Z.H.; Gao, F.; Liu, G.Z.; Chen, Q.Q.; Chen, S.; Weng, S.H.; Lin, L.Q.; et al. Antibodies to Type IV Collagen Induce Type 1 Autoimmune Pancreatitis. Inflammation 2016, 39, 592-600. [CrossRef] [PubMed]

85. Smyk, D.S.; Rigopoulou, E.I.; Koutsoumpas, A.L.; Kriese, S.; Burroughs, A.K.; Bogdanos, D.P. Autoantibodies in autoimmune pancreatitis. Int J. Rheumatol 2012, 2012, 940831. [CrossRef]

86. Miyoshi, H.; Uchida, K.; Taniguchi, T.; Yazumi, S.; Matsushita, M.; Takaoka, M.; Okazaki, K. Circulating naive and CD4+CD25high regulatory $\mathrm{T}$ cells in patients with autoimmune pancreatitis. Pancreas 2008, 36, 133-140. [CrossRef]

87. Uchida, K.; Kusuda, T.; Koyabu, M.; Miyoshi, H.; Fukata, N.; Sumimoto, K.; Fukui, Y.; Sakaguchi, Y.; Ikeura, T.; Shimatani, M.; et al. Regulatory T cells in type 1 autoimmune pancreatitis. Int. J. Rheumatol. 2012, 2012, 795026. [CrossRef]

88. Raphael, K.L.; Willingham, F.F. Hereditary pancreatitis: Current perspectives. Clin. Exp. Gastroenterol. 2016, 9, 197-207. [CrossRef]

89. Whitcomb, D.C. Genetic aspects of pancreatitis. Annu. Rev. Med. 2010, 61, 413-424. [CrossRef]

90. Dani, R.; Antunes, L.J.; Rocha, W.M.; Nogueira, C.E. AW23 and AW24 associated with chronic calcifying pancreatitis of alcoholic origin (author's transl). Arq. Gastroenterol. 1978, 15, 163-166. (In Portuguese)

91. Forbes, A.; Schwarz, G.; Mirakian, R.; Drummond, V.; Chan, C.K.; Cotton, P.B.; Bottazzo, G.F. HLA antigens in chronic pancreatitis. Tissue Antigens 1987, 30, 176-183. [CrossRef] [PubMed]

92. Homma, T.; Kubo, K.; Sato, T. HLA antigen and chronic pancreatitis in Japan. Digestion 1981, 21, $267-272$. [CrossRef] [PubMed]

93. Gullo, L.; Tabacchi, P.L.; Corazza, G.R.; Calanca, F.; Campione, O.; Labo, G. HLA-B13 and chronic calcific pancreatitis. Dig. Dis. Sci. 1982, 27, 214-216. [CrossRef] [PubMed]

94. Anderson, R.J.; Dyer, P.A.; Donnai, D.; Klouda, P.T.; Jennison, R.; Braganza, J.M. Chronic pancreatitis, HLA and autoimmunity. Int. J. Pancreatol. 1988, 3, 83-90. [CrossRef] 
95. Cavestro, G.M.; Frulloni, L.; Neri, T.M.; Seghini, P.; Nouvenne, A.; Zanetti, A.; Bovo, P.; Di Mario, F.; Okolicsanyi, L.; Cavallini, G. Association of HLA-DRB1*0401 allele with chronic pancreatitis. Pancreas 2003, 26, 388-391. [CrossRef]

96. Lee, B.; Adamska, J.Z.; Namkoong, H.; Bellin, M.D.; Wilhelm, J.; Szot, G.L.; Louis, D.M.; Davis, M.M.; Pandol, S.J.; Habtezion, A. Distinct immune characteristics distinguish hereditary and idiopathic chronic pancreatitis. J. Clin. Invest. 2020, 130, 2705-2711. [CrossRef]

97. Buch, S.; Schafmayer, C.; Volzke, H.; Seeger, M.; Miquel, J.F.; Sookoian, S.C.; Egberts, J.H.; Arlt, A.; Pirola, C.J.; Lerch, M.M.; et al. Loci from a genome-wide analysis of bilirubin levels are associated with gallstone risk and composition. Gastroenterology 2010, 139, 1942-1951. [CrossRef]

98. Von Kampen, O.; Buch, S.; Nothnagel, M.; Azocar, L.; Molina, H.; Brosch, M.; Erhart, W.; Von Schonfels, W.; Egberts, J.; Seeger, M.; et al. Genetic and functional identification of the likely causative variant for cholesterol gallstone disease at the ABCG5/8 lithogenic locus. Hepatology 2013, 57, 2407-2417. [CrossRef]

99. Habtezion, A.; Algul, H. Immune modulation in acute and chronic pancreatitis. Pancreapedia Exocrine Pancreas Knowl. Base 2016. [CrossRef]

100. Mrazek, A.A.; Porro, L.J.; Bhatia, V.; Falzon, M.; Spratt, H.; Zhou, J.; Chao, C.; Hellmich, M.R. Apigenin inhibits pancreatic stellate cell activity in pancreatitis. J. Surg. Res. 2015, 196, 8-16. [CrossRef]

101. Rickmann, M.; Vaquero, E.C.; Malagelada, J.R.; Molero, X. Tocotrienols induce apoptosis and autophagy in rat pancreatic stellate cells through the mitochondrial death pathway. Gastroenterology 2007, 132, 2518-2532. [CrossRef] [PubMed]

102. Tsang, S.W.; Zhang, H.; Lin, C.; Xiao, H.; Wong, M.; Shang, H.; Yang, Z.J.; Lu, A.; Yung, K.K.; Bian, Z. Rhein, a natural anthraquinone derivative, attenuates the activation of pancreatic stellate cells and ameliorates pancreatic fibrosis in mice with experimental chronic pancreatitis. PLoS ONE 2013, 8, e82201. [CrossRef] [PubMed]

103. Park, W.G.; Li, L.; Appana, S.; Wei, W.; Stello, K.; Andersen, D.K.; Hughes, S.J.; Whitcomb, D.C.; Brand, R.E.; Yadav, D.; et al. Unique circulating immune signatures for recurrent acute pancreatitis, chronic pancreatitis and pancreatic cancer: A pilot study of these conditions with and without diabetes. Pancreatology 2020, 20, 51-59. [CrossRef] [PubMed]

104. Zhang, R.; Shi, J.; Zhang, R.; Ni, J.; Habtezion, A.; Wang, X.; Hu, G.; Xue, J. Expanded CD14(hi)CD16(-) Immunosuppressive Monocytes Predict Disease Severity in Patients with Acute Pancreatitis. J. Immunol. 2019, 202, 2578-2584. [CrossRef] 